\title{
Early childhood obesity: a call for early surveillance and preventive measures
}

\section{J. Douglas Willms}

ß See related article page 240
The study of preschool children in Newfoundland and Labrador reported by Canning, Courage and Frizzell $^{1}$ in this issue (see page 240) indicates that about $8 \%$ of preschool children in Newfoundland and Labrador aged 3.5 to 5.5 years are obese, and a further $17 \%$ are overweight. This research emphasizes the importance of early surveillance based on direct assessment and makes a clear case for increased efforts at preventing and decreasing childhood obesity. Although the prevalence of overweight and obesity tends to be higher in the Atlantic provinces than in the rest of Canada, these results have implications for all provinces: in 1996 the reported prevalence of overweight in Canadian children aged 7 to 13 ranged from $23 \%$ to $36 \%$, and in every province the rate has at least doubled since $1981.2,3$

Early surveillance of childhood obesity does not need to be expensive; indeed, Canning and colleagues' study was based solely on height and weight data collected by public health nurses through regional health and community service boards. The public health infrastructure for immunizations and preschool screening could easily be extended to include the direct measurement of children's height and weight. However, several issues concerning the measurement of body fat and the definition of overweight and obesity are unresolved. Canning and colleagues estimated children's body mass index, defined as the child's weight divided by the square of his or her height $\left(\mathrm{kg} / \mathrm{m}^{2}\right)$. This index, when used with conventional definitions of overweight and obesity, can misclassify children who are particularly short or tall, ${ }^{4}$ or who are of Asian descent. ${ }^{5}$ Moreover, other indices based on weight and height, such as $\mathrm{kg} / \mathrm{m}^{3}$, may provide a more accurate measure of relative adiposity in very young children. ${ }^{6}$ Although there are "gold standard" procedures for measuring adiposity, including hydrodensitometry (underwater weighing), magnetic resonance imaging and computed tomography, these are impractical for population surveillance, especially of young children. ${ }^{7}$ Nevertheless, we need research using these procedures to validate indicators derived from direct measures of height and weight.

The cutoff points to define overweight and obesity are also problematic. Canning and colleagues used the method proposed by Cole and coauthors, ${ }^{8}$ which projects the prevalence of obesity and overweight for boys and girls at age 18 (using the standard adult cutoffs of $25 \mathrm{~kg} / \mathrm{m}^{2}$ for over- weight and $30 \mathrm{~kg} / \mathrm{m}^{2}$ for obesity) to earlier ages. This approach assumes that, on average, children maintain their relative position in a population throughout childhood. However, the accumulation of adipose tissue during childhood occurs primarily during the third trimester through to the end of the first year of life; during puberty; and in late adolescence. ${ }^{9}$ Each of these "filling periods" is followed by "stretching periods," when the percentage of fat in children's body mass falls. ${ }^{710}$ The increase in adipose cells during the first period occurs mainly through proliferation, and there is a further increase in the number of adipose cells during puberty. After adolescence, increases in body fat are mainly attributable to increases in the size of adipose cells. ${ }^{10}$ Consequently, it may be that the dramatic secular increases in obesity observed in Canada over the past 2 decades are associated more with changes in the prevalence of obesity for particular age groups, and these may vary among subpopulations. Although the method used by Cole and associates is perhaps the best one available, longitudinal research is required to develop age- and sex-related clinical measures of overweight and obesity, based on health risks and the developmental patterns of physically fit children.

Research on the risk factors associated with early childhood obesity is at an early stage. A study of Israeli army recruits found that youth whose birth weights were greater than 4000 grams were more than 3 times as likely to be obese at age $17 .{ }^{11}$ Other research has implicated smoking during pregnancy and parental obesity as significant risk factors. ${ }^{12-14}$ This research suggests an interaction between a child's genetic disposition to obesity and his or her environment during their mother's pregnancy and the first year of life.

The population of preschool children that Canning and colleagues studied in Newfoundland and Labrador was about halfway through the first stretching period. Therefore, many of these children were probably overweight or obese on their first birthday, and a disproportionate number would likely have had exceedingly high birth weights. Some of them may also have increased their proportion of body fat after their first birthday, when most children are reducing their proportion of fat. These findings emphasize the need for even earlier surveillance, perhaps at birth and at 6 and 12 months of age. They also stress the need for longitudinal research that follows children from the prenatal period through to late adolescence. 
Children who are obese or overweight when they enter school are at risk of being overweight and obese throughout their school years and into adulthood. They are more likely to experience health problems, including sleep apnea, asthma, fatty liver disease, type II diabetes and either early or delayed puberty. Children who are overweight or obese tend to have lower self-esteem, which in turn is associated with lower academic achievement. ${ }^{15}$ They are also more likely to be obese as adults and at risk of cardiovascular disease. ${ }^{16,17}$ If, at a conservative estimate, $20 \%$ to $25 \%$ of Canadian children are overweight or obese when they enter school, we need widespread multisectoral preventive efforts to ensure that they do not increase their risk of future problems during their school years. This will require health promotion policies in schools concerning diet and exercise, support from food industries to offer more nutritious food, support from the public and private sectors to facilitate healthy pregnancies, and local, provincial and national funding and legislation to improve the safety of neighbourhoods and increase access to playgrounds and recreational facilities. Leadership and advocacy from both health professionals and social scientists is required to bring about these changes.

Dr. Willms is director of the Canadian Research Institute for Social Policy and the Canada Research Chair in Human Development at the University of New Brunswick, Fredericton, NB

Competing interests: None declared.

\section{References}

1. Canning PM, Courage ML, Frizzell LM. Prevalence of overweight and obesity in a provincial population of Canadian preschool children. CMA7 2004; 171(3)240-2.

2. Willms JD, Tremblay MS, Katzmarzyk PT. Geographic and demographic variation in the prevalence of overweight Canadian children. Obes Res 2003 11/5:668-73.

3. Tremblay MS, Katzmarzyk PT, Willms JD. Temporal trends in overweight and obesity in Canada, 1981-96. Int 7 Obes Relat Metab Disord 2002;26(4):538-43.
4. Sardinha LB, Going SB, Teixeira PJ, Lohman TG. Receiver operating characteristic analysis of body mass index, triceps skin-fold thickness, and arm girth for obesity screening in children and adolescents. Am 7 Clin Nutr 1999; 70:1090-5

5. Wang J, Thornton JC, Russell M, Burastero S, Heymsfield S, Peirson RN Jr. Asians have lower body mass index (BMI) but higher percent body fat than do whites: comparisons of anthropomorphic measurements. Am 7 Clin Nutr 1994;60:23-8.

6. Franklin MF. Comparisons of weight and height relations in boys from four countries. Am 7 Clin Nutr 1999; 70 (Suppl):157s-62s.

7. Lobstein T, Baur L, Uauy R; for the IASO International Obesity Task Force Obesity in children and young people: a crisis in public health. Obes Rev 2004;5 (Suppl 1):4-85.

8. Cole TJ, Bellizzi MC, Flegal KM, Dietz WH. Establishing a standard definition for child overweight and obesity worldwide: international survey. $\mathrm{Br} \mathrm{Med}$ $72000 ; 320: 1-6$.

9. Widdowson EM. Changes in body proportions and composition during growth. In: Davis JA, Dobbing J, editors. Scientific foundation of pediatrics. London: William Heineman Medical; 1975. p. 153-63.

10. Wabitsch M. Molecular and biological factors with emphasis on adipose tissue development. In: Burniat W, Cole T, Lissau I, Poskitt EME, editors. Child and adolescent obesity: causes and consequences; prevention and management. New York: Cambridge University Press; 2002. p. 50-68.

11. Seidman DS, Laor A, Gale R, Stevenson DK, Danon YL. A longitudinal study of birth weight and being overweight in late adolescence. Am 7 Dis Child 1991;145:782-5.

12. Maffeis C, Micciolo R, Must A, Zaffanello M, Pinelli, L. Parental and perinatal factors associated with childhood obesity in north-east Italy. Int 7 Obes 1994;18:301-5

13. Curhan GC, Chertow GM, Willett WC, Spiegelman D, Colditz GA, Manson JE, et al. Birth weight and adult hypertension and obesity in women. Circulation 1996;94:1310-5.

14. Power C, Jefferis BJ. Fetal environment and subsequent obesity: a study of maternal smoking. Int 7 Epidemiol 2002;31: 413-9.

15. Tremblay MS, Inman JW, Willms JD. Relationships between physical activity, self-esteem, and academic achievement in ten- and eleven-year-old children. Pediatr Exer Sci 2000;11(3):312-23.

16. Freedman DJ, Serdula MK, Khan LK. The adult health consequences of childhood obesity. In: Chen C, Dietz WH, editors. Obesity in childhood and adolescence. Nestle Nutrition Workshop Series Pediatric Program. Vol. 49. Philadelphia: Lippincott Williams and Wilkins; 2002. p. 63-82.

17. Srinivasan SR, Bao W, Wattigney WA, Bereson GS. Adolescent overweight is associated with adult overweight and related multiple cardiovascular risk factors: the Bogalusa Heart Study. Metabolism 1996;45:235-40.

Correspondence to: Dr. J. Douglas Willms, Canadian Research Institute for Social Policy, University of New Brunswick, Ste. 300, Keirstead Hall, 38 Dineen Dr., Fredericton NB E3B 5A3; fax 506 447-3427;ksi@nbnet.nb.ca 